\title{
STUDENTS' PERCEPTION OF QUIPPER AS AN ONLINE PRACTICE TOOL FOR THE ENGLISH COMPUTER-BASED NATIONAL EXAMINATION
}

\author{
Satria Andy Kirana \\ Email: andykirana@gmail.com \\ VITA Junior High School \\ Surabaya, Indonesia
}

\begin{abstract}
This study is a descriptive case study that tries to follow the students' learning process in using Quipper, an e-learning platform to prepare them for the upcoming Computer-based National Examination. During the length of the research, the students' perception of Quipper as a practice tool will be gathered and presented, along with the aspects that need to be further developed in the future, and students' suggestions on how to develop Quipper into an e-learning platform with better functionality. Results of the study revealed that the students have positive perception towards Quipper with several notes about the need to revisit the functionalities and user interface according to what most students would be comfortable with as users. Further, the study also revealed critiques from the students for Quipper's future developments. Finally, on the basis of the critiques, some suggestions were also given by the students participated in this study. The suggestions consisted of conducting more research on another level of educations besides junior high school to get the overall idea of what the users from all age range need and also the need to conduct research on several other e-learning platforms.
\end{abstract}

Keywords: perception, quipper, computer-based national examination, technology acceptance model

\section{INTRODUCTION}

For the very first time in 2015, students at 556 schools (about $2 \%$ of all high schools in Indonesia) took an electronic version of the exam with the hope that it would cut down on costs to print and distribute the test. There were several drawbacks since many schools in Indonesia still haven't made investments in computers, yet there were benefits for schools that already own computers for it can be a 
way to take advantage of those facilities since it was also helpful to enhance students' computer literacy skills which are already considered as a basic need.

The computer-based exam system requires students to log in, download questions, which come together with multiple-choice answers, and then answer the questions by simply clicking on the right answer. Some students said that the computer-based tests have helped them fully concentrate on the questions, as they no longer need to worry about shading circles correctly, as students are required to do on the paper exams. All they have to do is enter their ID, password and then just click on the right answer. That also means that they don't need to worry about making mistakes when answering questions, such as shading over the line on conventional paper exams(Wirdana, 2015).

An idea then came up to use Quipper to help 9th grade students prepare for the upcoming Computer-based National Examination. Quipper is an online learning platform which provides lessons and tests for ages 8-18, created with the help of an experienced team of educators. Teachers can receive instant feedback on their students' performance; identify strengths and weaknesses in a matter of clicks, and save a lot of paperwork.

This study was conducted to find out the ninth grade Junior High School students' perception of Quipper as an online practice tool for the English Computer-based National Examination, to find out whether the ninth grade Junior High School students encounter any flaws or problems during their practice sessions for the English Computer-based National Examination using Quipper and also to find ways to improve Quipper as an exam practice tool using feedback given by the students.

Although the study has some limitations due to the small number of participants and possible chances for the students to be biased towards the teacher's preference, the study aims to help uncovering critical areas within the application of Quipper as an online practice tool for the Computer-based National Examination that needs to be improved based on the students' experience in the classroom and their suggestions. 


\section{LITERATURE REVIEW}

This part presents the related theories concerning e-learning, standardized testing and Technology Acceptance Model, and also some previous studies conducted by other researchers.

\section{E-learning}

E-learning can be approached from 2 basic angles - it can be seen either as an "educational process" or as a "set of tools supporting the educational process" (Kopecky, 2006). Consequently, there is a wide range of definitions that may differ according to the organization and the way of e-learning usage.

For the purpose of this study the term e-learning can be illustrated by comparing and combining the following definitions: "Elearning is understood as a multimedia support of educational process using modern information and communication technologies usually implemented through computer networks. Its main task is free and in time and space unlimited access to knowledge" (Kopecky, 2006).

Synchronous online e-learning requires a constant connection to the net while students communicate with their teachers in real time, which means they can chat, virtually telephone or video conference. Asynchronous online e-learning is presented by communication among participants who are not connected to a net at the same time. They communicate through sent messages in discussion forums or they send e-mails. Offline e-learning does not require a participant's computer to be connected to any net. Study materials are provided thanks to memory tracks, such as CD-ROMs, DVD-ROMs or disks. This is hugely used at basic and secondary schools where present education is joined with an e-learning multi-media support to create so-called blended learning (Kopecky, 2006).

The advantages of e-learning can be summarized as follows (Zlamalova, 2006):

1. higher efficiency of education (flexibility, well-arranged structure with small units, multi-media elements);

2. accessibility, so called just-in-time;

3. individual attitude to a student; 
4. low costs of education (for a society as a whole, for educational institution and also for a student);

5. easy up-dating of an educational content and used methods;

6. more possibilities for knowledge testing of a student;

7. high rate of interactivity;

8. easy administration;

9. increase in ICT skills of students and also teachers.

While the disadvantages of e-learning can be summarized as follows (Zlamalova, 2006):

1. dependence on technology;

2. incompatibility of components;

3. unsuitability for certain types of courses;

4. unsuitability for certain types of students;

5. bad solution of interactivity (too much or absence);

6. high initial costs for an educator (to prepare and start the study).

\section{Standardized Testing in Indonesia}

Standardized testing has long been the dominant feature in the education system in the Republic of Indonesia. Standardized testing has long been the dominant feature in the education system in the Republic of Indonesia. It was explained by Furqon (2004) that in the period of 1965-1971 the Ujian Negara (State Exam) was done for almost all subjects for students at the end of each of the school level, elementary, middle school, and high school. Although, a non-standardized testing policy was endorsed for the next 7 years, where schools were given the authority to design and hold the final exam based on the guidelines from the central government, in 1980 Indonesia went back to the centralized exam system. The EvaluasiBelajarTahapAkhirNasional (National Final Learning Evaluation), commonly shortened as Ebtanas, was implemented for 21 years.

As from the early 2015, the National Examination changed its function from being the only aspect that can determine a student's graduation into only a tool to measure students' competence and map schools' performances. There is no longer a minimum passing grade, but the ministry has set a minimum standard score for each subject. 
For a student to be judged competent, for example, he or she should earn a score of at least 5.5 on a scale of 1-10 for each subject.

Those who score below the standard are allowed to take the exam again. Graduating high school students can use the results of their National Examination to apply for university. Junior high graduates can use them to enroll in a state high school of their choice.

\section{Quipper in Indonesia}

The teaching and learning process at secondary education level, both junior and senior high schools in Indonesia, has made a significant progress with the emergence of e-learning platforms, one of which is Quipper. Founded by Masayuki Watanabe in London in December 2010, Quipper is an e-learning platform that provides 2 main services

1. Quipper School Learn (learn.quipper.com) is a special portal where students can access and read course materials, answer questions, send a message to the teachers, and learn to see the performance of her classmates.

2. Quipper School Link (link.quipper.com) is special portal for teachers where they can set up tasks, see the development of the students, send a message to students, manage the classroom, and make online classes.

Quipper is not the first e-learning platform that supports the teaching and learning process in Indonesia. There are several previously existing names such as Kelase and Student Book. Quipper though, has several striking differences by becoming not only a platform to support the teaching and learning process, but also a provider of learning materials for at least 10 subjects commonly taught in public and private schools in Indonesia, with more than 1,300 freeto-choose topics.

\section{Technology Acceptance Model}

The technology acceptance model proposes that perceived usefulness, perceived ease of use, and attitudes are important determinants of technology usage intentions and in turn usage behavior. TAM has been widely used to predict user acceptance and 
use, based on perceived usefulness, perceived ease of use, and attitude (Davis, 1989).

Davis (1989) and Davis, Bagozzi, \&Warshaw (1989) developed the TAM by adapting the Theory of Reasoned Action (TRA) (Fishbein \& Ajzen, 1975), to understand the causal chain linking external factors to IT usage intention and actual use in a workplace. TAM was developed under contract with IBM Canada Ltd. in the mid-1980s where it was used to evaluate the market potential for a variety of then-emerging PC-based applications in the area of multimedia, image processing, and pen-based computing in order to guide investments in new product development (Davis, 1989). Many IT studies have replicated TAM or used the TAM instrument (which has empirically proved to have high validity) extensively to investigate a range of issues in the area of user acceptance (Igbaria, Zinatelli, Cragg, \& Cavaye, 1997; Mathieson, 1991).

\section{Teachers' and Students' Voices toward the Use of Quipper School on English Subject in SMPN 40 Semarang.}

This previous study was presented by Kusumawardani, A. D., \&Faizah, A. (2017). The qualitative study aims to investigate how Quipper School has been used. Furthermore, it also focuses on teachers' and students' perception toward the implementation. This study was conducted at SMPN 40 Semarang, one of public junior high schools in Semarang, Central Java, Indonesia. The data was gathered by conducting semi-structured interview, both English teachers and students. The interviews were recorded, were transcribed and were interpreted in order to have detail information on how Quipper School has been used and the teachers' perception as well as the students'. It was found that during the implementation, the application helps the teachers to administrate students' work and progress during the learning process. Quipper School makes teaching-learning process more fun for the students. Students' views this learning more effective and very helpful compared with the previous way of learning. 


\section{METHOD}

In this study, the case from the actual series of preparations to help the students for the Computer-based National Examinations (UNBK) this upcoming May was firstly defined. Second, the research questions were formulated by looking at the defined case. Third, a survey was done to obtain the needed data regarding the students' perception of Quipper as an online practice tool for the English Computer-based National Exam by distributing a questionnaire to the students to get data on their perception. And then fourth, the data collected was then analyzed through coding and categorization under several themes (see Figure 3.1.).

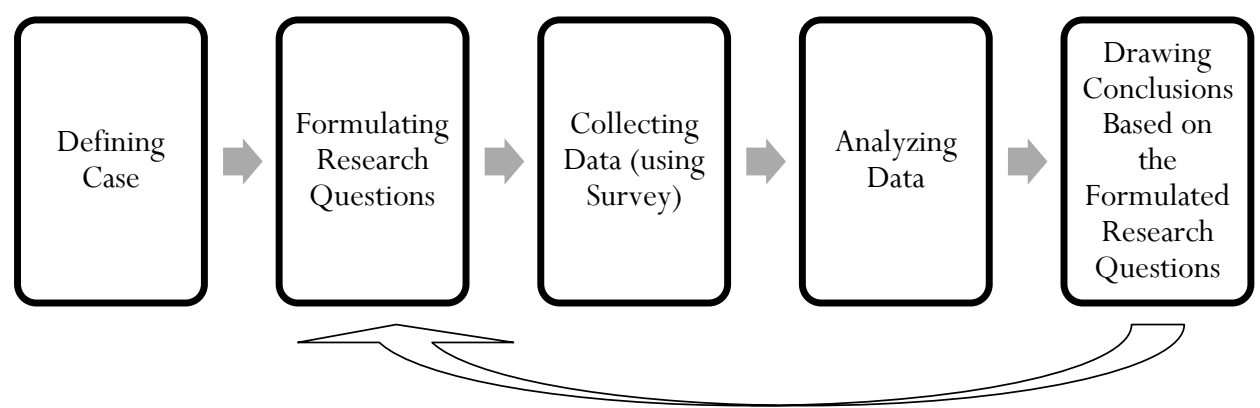

Figure 1. Research Design

\section{Participants}

The participants in the research study were 22 students of 9E, 1 out of 5 ninth grade classes at the school. They were recruited as participants using a purposive sampling technique based on 3 underlying reasons. The first reason was due to the variety of classroom configuration that the school had in one week. The various configurations were implemented to accommodate subjects such as Mandarin and Life Skill which were taught by part-time teachers, mainly because the school was the one adapting to the part-time teachers' schedule. The second reason was due to the students' nearly equal exposure to both Quipper and paper mock tests as a medium to practice for the National Examination. The third reason was due to the limited time available left. 


\section{Research Instrument}

During this study, one instrument was be used to gather data. In order to obtain students' perceptions of Quipper as an online practice tool for the English Computer-based National Examination, Students' Perceptions about Quipper Questionnaire (SPQ-Q) was be used.

Before the SPQ-Q is distributed, it was tried out first to a fraction of the group participant used in the study. It is important to conduct a questionnaire try out due to several purposes, first is to check whether participants understand the terminology used in the questionnaire. Second is to check whether emotive questions are not used as they make people defensive and could invalidate their answers. The third purpose is to check whether leading questions are not used as they could bias the respondent's answer, and the last is to ensure that the questionnaire can be completed in an appropriate time frame.

\section{The Source of Data and Data}

The source of data was the 22 students in class 9E that become the participants of the study. The data gathered in this study were the students' perception, students' critique, and also the students' suggestions.

Table 1. Research Questions - Source of Data - Data - Unit of Analysis

\begin{tabular}{|c|c|c|c|}
\hline Research Questions & $\begin{array}{l}\text { Source } \\
\text { of Data }\end{array}$ & Data & $\begin{array}{l}\text { Unit of } \\
\text { Analysis }\end{array}$ \\
\hline $\begin{array}{l}\text { 1. What are students' } \\
\text { perceptions of Quipper as } \\
\text { an online practice tool for } \\
\text { the English Computer- } \\
\text { based National } \\
\text { Examination? }\end{array}$ & \multirow{2}{*}{ 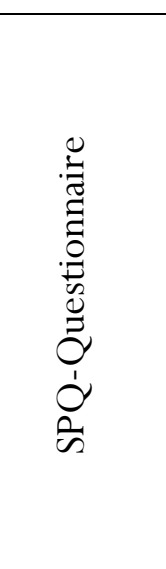 } & $\begin{array}{l}\text { Students' } \\
\text { response }\end{array}$ & Likert scale \\
\hline $\begin{array}{l}\text { 2. Is there any aspect that } \\
\text { needs to be further revised } \\
\text { and developed? }\end{array}$ & & $\begin{array}{l}\text { Students' } \\
\text { response }\end{array}$ & $\begin{array}{l}\text { Open-ended } \\
\text { Problems / } \\
\text { Critique form }\end{array}$ \\
\hline
\end{tabular}




\begin{tabular}{|l|l|l|l|}
\hline $\begin{array}{l}\text { 3. How can Quipper's } \\
\text { functionality as an online } \\
\text { exam practice tool be } \\
\text { improved? }\end{array}$ & $\begin{array}{l}\text { Students' } \\
\text { response }\end{array}$ & $\begin{array}{l}\text { Suggestions } \\
\text { form }\end{array}$ \\
\hline
\end{tabular}

The data collected in this study was taken in the form of response percentage from the Likert-scale items on the SPQ Questionnaire and also students' responses from the open-ended CRITIQUE and SUGGESTION sections in the questionnaire. The survey highlighted on 2 major themes; Perceived Usefulness and Perceived Ease of use.

Perceived Usefulness is defined as 'the degree to which a person believes that using a particular system would enhance his or her job performance' (Davis, 1989). In the context of this study, perceived usefulness is defined as the perception of how students see improvement in learning effects through using Quipper.

Perceived ease of use on the other hand is defined as: 'the degree to which a person believes that using a particular system would be free of effort' (Davis, 1989). This means that if a user subjectively sees a system as easy to use, the user is more willing to continue using that system. In the context of this study, perceived ease to use can be described as the ease the students feel for adopting Quipper to help them learn for the Computer-based National Examination, and therefore Perceived Ease of Use has a significant relationship with the students' satisfaction (Sun et al, 2008).

\section{Triangulation}

To minimize researcher's bias and to strengthen the design of the study, special strategies were used to enhance the reliability and validity. In this case study, content validity was enhanced through literature review and by comparing the findings from the SPQ-Q with the result from focus group discussion session moderated by the researcher.

Focus group discussions are particularly effective for identifying agreement across a group and for eliciting suggestions for improvement (Krueger, 1988). They can also help enhance and 
validate surveys or scales because they allow for question clarification and follow-up questions to probe vague or unexpected responses. When conducted by a well-planned moderator who can use the interaction to motivate students to actively participate, a focus group can generate a wealth of useful information to enhance and validate the result of this case study.

\section{FINDINGS AND DISCUSSION}

To answer the first research question about the students' perception posed at the beginning of this study, Table 2 showed overall positive perceptions which were conveyed through the participants' responses towards survey item \#1 until \#8. The average total response showed that $63 \%$ and $36 \%$ of the students who participated in the study gave positive perceptions through their "Agree" and "Strongly Agree" responses, while the other 1\% responded "Disagree".

Table 2. Survey Result - Perceived Usefulness

\begin{tabular}{|c|c|c|c|c|c|c|c|}
\hline THEME & $\#$ & SURVEY ITEM & 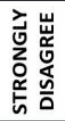 & 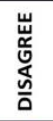 & 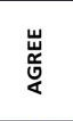 & 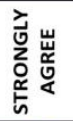 & $\stackrel{\frac{1}{5}}{\stackrel{5}{\circ}}$ \\
\hline \multirow{6}{*}{ 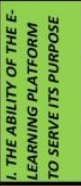 } & \multirow[t]{2}{*}{1} & \multirow{2}{*}{$\begin{array}{l}\text { Quipper suits my need to practice for the English Computer- } \\
\text { based National Examination. }\end{array}$} & & 1 & 9 & 12 & 22 \\
\hline & & & $0 \%$ & $5 \%$ & $41 \%$ & $55 \%$ & $100 \%$ \\
\hline & \multirow[t]{2}{*}{2} & \multirow{2}{*}{$\begin{array}{l}\text { Quipper enables me to learn and practice for the English } \\
\text { Computer-based National Examination anywhere easily. }\end{array}$} & & & 11 & 11 & 22 \\
\hline & & & $0 \%$ & $0 \%$ & $50 \%$ & $50 \%$ & $100 \%$ \\
\hline & \multirow[t]{2}{*}{3} & \multirow{2}{*}{$\begin{array}{l}\text { Quipper enables me to learn and practice for the English } \\
\text { Computer-based National Examination anytime easily. }\end{array}$} & & & 15 & 7 & 22 \\
\hline & & & $0 \%$ & $0 \%$ & $68 \%$ & $32 \%$ & $100 \%$ \\
\hline \multirow{10}{*}{ 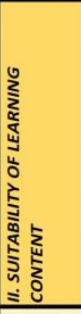 } & \multirow[t]{2}{*}{4} & \multirow[t]{2}{*}{ Quipper has a well-suited learning content. } & & & 13 & 9 & 22 \\
\hline & & & $0 \%$ & $0 \%$ & $59 \%$ & $41 \%$ & $100 \%$ \\
\hline & \multirow[t]{2}{*}{5} & \multirow{2}{*}{$\begin{array}{l}\text { Quipper contains suitable modules for } 9 \text { th graders according } \\
\text { to the national standards (KTSP \& 2013). }\end{array}$} & & & 15 & 7 & 22 \\
\hline & & & $0 \%$ & $0 \%$ & $68 \%$ & $32 \%$ & $100 \%$ \\
\hline & \multirow[t]{2}{*}{6} & \multirow{2}{*}{$\begin{array}{l}\text { Quipper contains suitable chapters for 9th graders according } \\
\text { to the national standards (KTSP \& 2013). }\end{array}$} & & & 16 & 6 & 22 \\
\hline & & & $0 \%$ & $0 \%$ & $73 \%$ & $27 \%$ & $100 \%$ \\
\hline & \multirow[t]{2}{*}{7} & \multirow{2}{*}{$\begin{array}{l}\text { Quipper contains suitable lessons for 9th graders according to } \\
\text { the national standards (KTSP \& 2013). }\end{array}$} & & 1 & 16 & 5 & 22 \\
\hline & & & $0 \%$ & $5 \%$ & $73 \%$ & $23 \%$ & $100 \%$ \\
\hline & \multirow[t]{2}{*}{8} & \multirow{2}{*}{$\begin{array}{l}\text { Quipper contains suitable exercises for 9th graders according } \\
\text { to the national standards (KTSP \& 2013). }\end{array}$} & & & 15 & 7 & 22 \\
\hline & & & $0 \%$ & $0 \%$ & $68 \%$ & $32 \%$ & $100 \%$ \\
\hline & & AVERAGE PERCENTAGE & $0 \%$ & $1 \%$ & $63 \%$ & $36 \%$ & $100 \%$ \\
\hline
\end{tabular}

The responses that the students gave for survey item \#1 until \#8 covered the Perceived Usefulness (PU) aspect from the Technology Acceptance Model (TAM) and the data taken from the overall response percentage was used to answer the first research 
question, which asked about the students' perception of Quipper as an Online Practice Tool for the Computer-based National Examination.

Table 3 showed overall positive perceptions that were conveyed through the participants' responses towards survey item \#1 until \#13. The average total response showed that 35\% and $46 \%$ of the students who participated in the study gave positive perceptions through their "Agree" and "Strongly Agree" responses, while the other 16\% responded "Disagree" and 1\% responded "Strongly Disagree". Although there was a slightly higher percentage in the "Disagree" area that was around $16 \%$ (12\% higher than the amount of "Disagree" response given for the Perceived Usefulness section), 81\% can still be considered as a significantly positive response.

Table 3. Survey Result - Perceived Usefulness

\begin{tabular}{|c|c|c|c|c|c|c|c|}
\hline THEME & $\#$ & SURVEY ITEM & 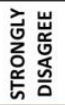 & 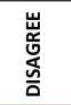 & 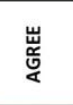 & 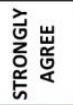 & 峁 \\
\hline \multirow{8}{*}{ 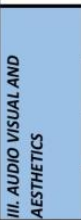 } & \multirow[t]{2}{*}{1} & \multirow{2}{*}{$\begin{array}{l}\text { Quipper is designed with clear and visually appealing pages } \\
\text { and navigation buttons. }\end{array}$} & & $\overline{1}$ & 10 & 11 & 22 \\
\hline & & & $0 \%$ & $5 \%$ & $45 \%$ & $50 \%$ & $100 \%$ \\
\hline & \multirow[t]{2}{*}{2} & \multirow{2}{*}{$\begin{array}{l}\text { Quipper uses relevant images/illustrations/animations in all its } \\
\text { lessons and exercises }\end{array}$} & & 4 & 9 & 9 & 22 \\
\hline & & & $0 \%$ & $18 \%$ & $41 \%$ & $41 \%$ & $100 \%$ \\
\hline & \multirow[t]{2}{*}{3} & \multirow{2}{*}{$\begin{array}{l}\text { Quipper uses text and images which are presented in a } \\
\text { proportionate fashion (not overlapping/overpowering one }\end{array}$} & & 2 & 11 & 9 & 22 \\
\hline & & & $0 \%$ & $9 \%$ & $50 \%$ & $41 \%$ & $100 \%$ \\
\hline & \multirow[t]{2}{*}{4} & \multirow{2}{*}{$\begin{array}{l}\text { Quipper uses sound effects that are moodlifting and suitable } \\
\text { with its theme. }\end{array}$} & & 9 & 7 & 6 & 22 \\
\hline & & & $0 \%$ & $41 \%$ & $32 \%$ & $27 \%$ & $100 \%$ \\
\hline \multirow{18}{*}{ 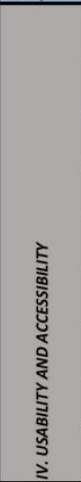 } & \multirow[t]{2}{*}{5} & \multirow{2}{*}{$\begin{array}{l}\text { Quipper has navigation buttons that are consistent in } \\
\text { placement and size. }\end{array}$} & & 1 & 12 & 9 & 22 \\
\hline & & & $0 \%$ & $5 \%$ & $55 \%$ & $41 \%$ & $100 \%$ \\
\hline & \multirow[t]{2}{*}{6} & \multirow{2}{*}{$\begin{array}{l}\text { Quipper has navigation buttons that can help me explore the } \\
\text { entire platform without trying too hard. }\end{array}$} & & 3 & 14 & 5 & 22 \\
\hline & & & $0 \%$ & $14 \%$ & $64 \%$ & $23 \%$ & $100 \%$ \\
\hline & \multirow[t]{2}{*}{7} & \multirow[t]{2}{*}{ Quipper has consistent and non-confusing visual themes. } & & 2 & 14 & 6 & 22 \\
\hline & & & $0 \%$ & $9 \%$ & $64 \%$ & $27 \%$ & $100 \%$ \\
\hline & \multirow[t]{2}{*}{8} & \multirow{2}{*}{$\begin{array}{l}\text { Quipper presents its information in a clear and easily readable } \\
\text { way. }\end{array}$} & & 2 & 13 & 7 & 22 \\
\hline & & & $0 \%$ & $9 \%$ & $59 \%$ & $32 \%$ & $100 \%$ \\
\hline & \multirow[t]{2}{*}{9} & \multirow[t]{2}{*}{ Quipper displays its instructions clearly. } & & 1 & 14 & 7 & 22 \\
\hline & & & $0 \%$ & $5 \%$ & $64 \%$ & $32 \%$ & $100 \%$ \\
\hline & \multirow[t]{2}{*}{10} & \multirow[t]{2}{*}{ Quipper displays its content using clear and easily-adjusted fon } & & 2 & 9 & 11 & 22 \\
\hline & & & $0 \%$ & $9 \%$ & $41 \%$ & $50 \%$ & $100 \%$ \\
\hline & \multirow[t]{2}{*}{11} & \multirow{2}{*}{$\begin{array}{l}\text { Quipper works well whenever I access it from my phone / } \\
\text { tablet. }\end{array}$} & 2 & 13 & 4 & 3 & 22 \\
\hline & & & $9 \%$ & $59 \%$ & $18 \%$ & $14 \%$ & $100 \%$ \\
\hline & \multirow[t]{2}{*}{12} & \multirow[t]{2}{*}{ Quipper works well whenever I access it from my PC / laptop. } & & 2 & 10 & 10 & 22 \\
\hline & & & $0 \%$ & $9 \%$ & $45 \%$ & $45 \%$ & $100 \%$ \\
\hline & \multirow[t]{2}{*}{13} & \multirow{2}{*}{$\begin{array}{l}\text { Quipper's versatility to change from desktop to mobile and } \\
\text { vice versa helps my practice process significantly. }\end{array}$} & & 3 & 13 & 6 & 22 \\
\hline & & & $0 \%$ & $14 \%$ & $59 \%$ & $27 \%$ & $100 \%$ \\
\hline & & AVERAGE PERCENTAGE & $1 \%$ & $16 \%$ & $49 \%$ & $35 \%$ & $100 \%$ \\
\hline
\end{tabular}

The responses that the students gave for survey item \#1 until \#13 covered the Perceived Ease of Use (PEU) aspect from the Technology Acceptance Model (TAM) and the data taken from the overall response percentage was also used to answer the first research question, alongside the responses for the previously mentioned 
Perceived Usefulness section. The joined responses convey that the students's perception of Quipper as an online practice tool was good and it was proven by using the high percentage in the positive area of the Likert Scale section in the questionnaire.

The answer to the second research question posed at the beginning of this study was taken from the participants' critiques gathered through one of the questionnaire's open ended sections as displayed in Table 4, Table 5, and Table 6 . The critiques were then categorized into topics according to the aspects that the students considered worth paying attention to. After being categorized, there were three topics that according to the students became the points that the software developers need to improve through updates and debugging.

The first critique topic as displayed in Table 4. was about Quipper's mobility and compatibility, some of the frequently mentioned critiques were concerning about the slow page loading, access difficulty, mobile-to-desktop incompatibility, laggy performance, etc. The students were instructed to write their critiques next to the Likert Scale section used to gather the data about student perception.

Table 4. Students' Critiques - Mobility \& Compatibility

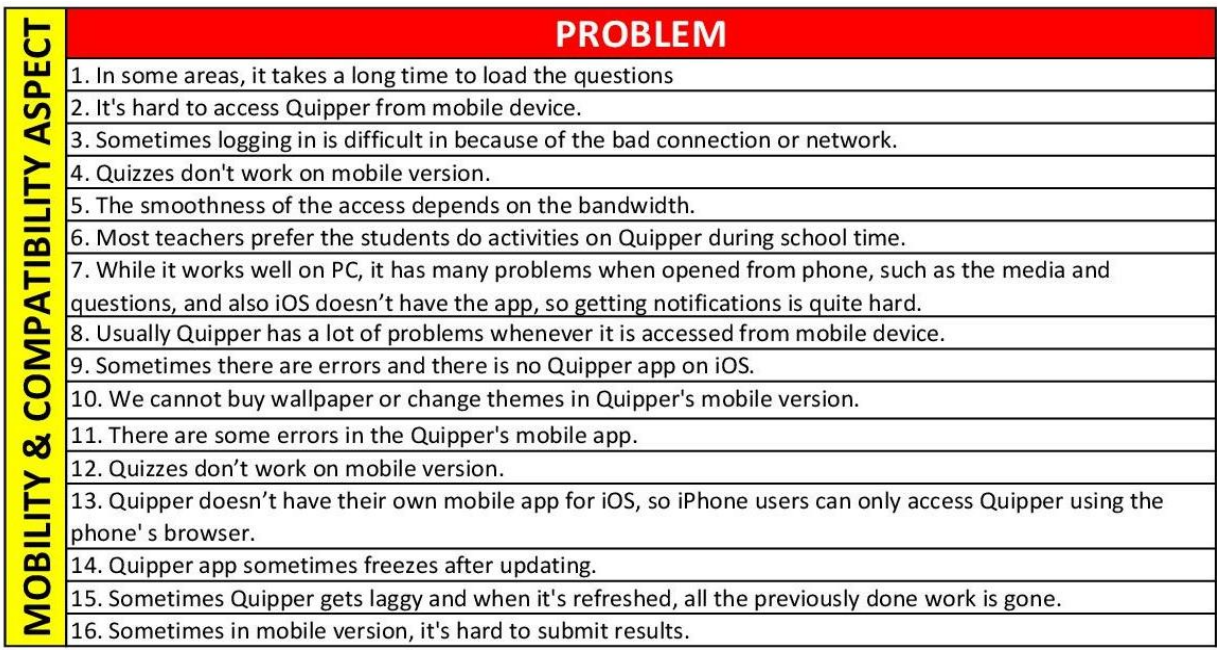


The second critique topic as displayed in Table 5 was about Quipper's content, some of the frequently mentioned critiques were concerning about the difficulty level of the questions, some questions which were considered unimportant, the ambiguity of some of the questions, grammatical mistakes, etc.

\section{Table 5. Students' Critiques - Content}

\begin{tabular}{|c|c|}
\hline \multirow{5}{*}{ 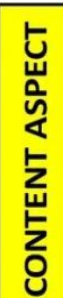 } & PROBLEM \\
\hline & 1. The questions are too easy. \\
\hline & 2. Quipper sometimes asks unimportant questions. \\
\hline & $\begin{array}{l}\text { 3. Sometimes the questions were too ambiguous and the answer keys were } \\
\text { different from the correct answer. }\end{array}$ \\
\hline & 4. There are some grammar mistakes. \\
\hline
\end{tabular}

The third critique topic as displayed in Table 6 was about Quipper's audio visual aspects, some of the frequently mentioned critiques were concerning about the childish visual layout, sound effects which sometimes got too distracting, inconsistent picture size, picture-totext irrelevance, etc.

Table 6. Students' Critiques - Audio Visual

\begin{tabular}{|l|l|}
\hline \multicolumn{1}{|c|}{ PROBLEM } \\
\hline 1. Sometimes the images and videos etc just can't be displayed and irrelevant. \\
\hline 2. It's too childish but it looks nice. \\
\hline 3. Sometimes the images are not relevant. \\
\hline 4. Sometimes the media overpower the texts when opened through phone / tablet, causing the text \\
to be unclear. \\
\hline \begin{tabular}{l} 
5. Some pictures are too small to see and the enlargement option doesn't really help much. \\
\hline 6. The sound effects are more than often annoying and quite surprising.
\end{tabular} \\
\hline 7. The sound effects are not suitable with the theme. \\
\hline 8. Sound effects are not necessary. \\
\hline 9. It's not suitable with the theme because every theme has he same set of sound effects. \\
\hline 10. In tryouts, there were no sound. \\
\hline 11. The notification sound isn't really that audible enough. \\
\hline 12. The setting button for the notification is a bit hard to locate. \\
\hline 13. The information is sometimes cannot be understood and the answer keys are sometimes wrong. \\
\hline 14. Quipper didn't present its information in a brief way. \\
\hline
\end{tabular}

The answer to the third and last research question posed at the beginning of this study was taken from the participants' suggestions gathered through one of the questionnaire's open ended sections as 
displayed in Table 7, Table 8, and Table 9. Like the previous section about the critiques, the students' suggestions were then categorized into topics according to the aspects that the students considered worth paying attention to. After being categorized, there were three topics that according to the students became the alternative options for the software developers to troubleshoot the things being critiqued by the students.

The first suggestion topic as displayed in Table 7 was about Quipper's mobility and compatibility, some of the frequently mentioned suggestions were concerning about the mobile-to-desktop adjustment, suggestions for revisions and updates, suggestions for bug fixes, the possibility of having an auto-save feature, etc.

Table 7. Students' Suggestions - Mobility

\begin{tabular}{|c|c|c|}
\hline \multirow{8}{*}{ 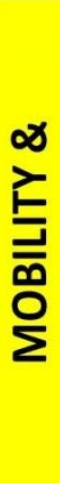 } & \multirow{8}{*}{ 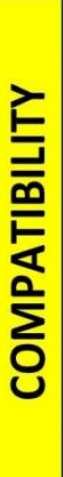 } & SUGGESTIONS \\
\hline & & $\begin{array}{l}\text { 1. Quipper should make some adjustments and changes on their mobile } \\
\text { version so that people who open it from their phone can do their work } \\
\text { even better. }\end{array}$ \\
\hline & & 2. Please uprade Quipper so that it can be more accessible. \\
\hline & & $\begin{array}{l}\text { 3. Update and make revisions so we can buy wallpapers or change themes } \\
\text { in Quipper mobile version. }\end{array}$ \\
\hline & & 4. Make the quizzes available for the mobile version. \\
\hline & & $\begin{array}{l}\text { 5. Quipper should have a mobile app for iOS platform so that iPhone users } \\
\text { can access it easily. }\end{array}$ \\
\hline & & 6. Quipper needs to fix the bug in the mobile app. \\
\hline & & 7. Quipper should have an auto-save feature. \\
\hline
\end{tabular}

The second suggestion topic as displayed in Table 8 was about Quipper's content. Some of the frequently mentioned suggestions were suggestions to increase the difficulty of the questions, suggestions for grammar re-check, etc.

Table 8. Students' Suggestions - Content

\begin{tabular}{|c|c|}
\hline \multirow{5}{*}{ 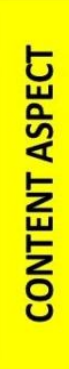 } & SUGGESTIONS \\
\hline & 1. Quipper should make the questions more challenging. \\
\hline & $\begin{array}{l}\text { 2. Quipper needs to sort the questions that are going to be given } \\
\text { to the user. }\end{array}$ \\
\hline & $\begin{array}{l}\text { 3. Quipper should make notifications for teachers to check } \\
\text { questions before asking students to do it. }\end{array}$ \\
\hline & $\begin{array}{l}\text { 4. Quipper should re-check the grammar in the sentences used } \\
\text { in the test }\end{array}$ \\
\hline
\end{tabular}


The third suggestion topic as displayed in Table 9 was about Quipper's audio visual aspect, some of the frequently mentioned suggestions were suggestion about enlargement options for images that became a part of the questions, suggestions to have on/off toggle for the audio, etc.

Table 9. Students' Suggestions - Audio Visual

\begin{tabular}{|c|c|}
\hline \multirow{9}{*}{ 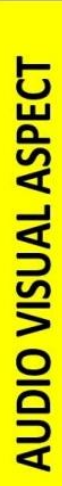 } & SUGGESTIONS \\
\hline & 1. Quipper should make the user able to enlarge the pictures significantly. \\
\hline & $\begin{array}{l}\text { 2. The sound effects should just be turned of because it's rather annoying and } \\
\text { not moodlifting. }\end{array}$ \\
\hline & 3. Quipper needs to add sound effects that are suitable with the theme. \\
\hline & 4. Quipper should change the sound effects \\
\hline & 5. Quipper needs to provide songs for its users to enjoy while practicing \\
\hline & 6. Quipper needs to make the notification sound louder. \\
\hline & $\begin{array}{l}\text { 7. Quipper needs to make the setting button for the notification easier to } \\
\text { locate. }\end{array}$ \\
\hline & $\begin{array}{l}\text { 8. The instructions should be clearer because they can confuse and mislead } \\
\text { students to the wrong answer. }\end{array}$ \\
\hline & 9. Quipper needs to present the information in a simpler way \\
\hline
\end{tabular}

\section{CONCLUSION AND SUGGESTIONS}

Based on the study results, the conclusion was that the most important finding is that the students' perceptions of Quipper as an online practice tool for the English Computer-based National Examination was mainly influenced by how Quipper had managed to correlate with the participants' educational needs and expectations. If the platform had the 'right' functionality, students would likely to accept the system. On the other hand, if the platform did not provide the needed functions, students will turn to using other platforms instead. This means that IT engineers and technopreneurs within the world of education needed to make sure that the functionality of an elearning platform corresponds with the users' needs.

As a final point it is clear that there is plenty of room and opportunity to conduct more studies investigating user perception and acceptance of technology in the educational sector and areas related to it. In the future, hopefully there would be studies that investigate a number of different E-learning platforms to further develop and modify the findings from this study. 
It would also be suggested that in the future there would be studies on user acceptance that highlight on investigating the educational technology needs of students in other level besides junior high school such as elementary and upper secondary schools. As the educational technology needs of the students as users play a vital role in an e-learning platform's system acceptance.

Suggested researches like the above could help e-learning platform developers to bring their products up to the next level and eventually provide IT-professionals within the world of educational with a better idea for what kind of functionality is important to students.

\section{REFERENCES}

Aaltio, I., \&Heilmann, P. (2010). Case study as a methodological approach. Encyclopedia of case study research, 67-78.

Chapelle, C. (2003). English language learning and technology: Lectures on applied linguistics in the age of information and communication technology (Vol. 7). John Benjamins Publishing.

Davis, F. D. (1989). Perceived usefulness, perceived ease of use, and user acceptance of information technology. MIS quarterly, 319340.

Fishbein, M., \&Ajzen, I. (1977). Belief, attitude, intention, and behavior: An introduction to theory and research.

Furqon. (2004). MasihPerlukahUjianNasional. Retrieved from http://www.pikiran-rakyat.com/cetak/1204/23/0804.htm.

Igbaria, M., Zinatelli, N., Cragg, P., \&Cavaye, A. L. M. (1997). Personal computing acceptance factors in small firms: a structural equation model.MIS Quarterly, 21(3), 279-305. http: / / doi.org/10.2307/249498

Kopecký, K. (2006). E-learning (nejen) pro pedagogy. Olomouc: Hanex, 2006. ISBN 80-85783-50-9.

Krueger, R. A. (1988). Focus groups: A practical guide for applied research. Newbury Park, CA: Sage Publications.

Kusumawardani, A. D., \&Faizah, A. (2017). Teachers and Students' Voices Toward the Use of Quipper School on English Subject in 
SMPN 40 Semarang. In UNNES-TEFLIN National Seminar (pp. 4755).

Mulyono, H. (2016). Using Quipper as an Online Platform for Teaching and Learning English as a Foreign Language. Teaching English with Technology, 16(1), 59-70.

Sun, P. C., Tsai, R. J., Finger, G., Chen, Y. Y., \&Yeh, D. (2008).

What drives a successful e-Learning? An empirical investigation of the critical factors influencing learner satisfaction. Computers \& education, 50(4), 1183-1202.

Timmons, V., \& Cairns, C. (2009). "Case Study Research in Education." Encyclopedia of Case Study Research. Ed. Albert J. Mills, Gabrielle Durepos, and EldenWiebe. Thousand Oaks, CA: SAGE, 2009. 100-04. SAGE Reference Online. Web. 21 Feb. 2012. Retrieved from http:// sageereference.com.proxy.lib.umich.edu/view/ casestud $\mathrm{y} / \mathrm{n} 36 . \mathrm{xml}$ ?rskey ${ }_{\mathrm{o}} 9$ na7M\&result $=1$ \& $\mathrm{q}=$ case $\% 20$ study $\% 20$ education

Venkatesh, V., \& Davis, F. D. (2000). A theoretical extension of the technology acceptance model: Four longitudinal field studies. Management science, 46(2), 186-204.

Wirdana, A. (2015). From Shady Circles to Clicks: Indonesia Computerized Exams boldly piloted. Retrieved February 18, 2016, from http:/ / www.establishmentpost.com/from-shady-circles-toclicks-indonesia-computerised-exams-piloted/

Zlamalova, H. (2006). Distančnívzděláváníaelearning: Učební text pro distančnístudium. Prague: Univerzita Jana AmoseKomenského. 
